Jpn. J. Hosp. Pharm.

$\left[\begin{array}{lll}21(3) & 185-190 & (1995)\end{array}\right]$

\title{
血墏中ゾニサミド濃度に及ぼす併用薬の影響
}

\author{
篠田正彦 $* \uparrow^{3}$ ，秋田昌宏 $\dagger^{2}$ ，長谷川雅哉 $\uparrow^{2}$ ，長谷川高明 $\uparrow^{1,2}$ ，鍋島俊隆 $\uparrow^{1,2}$ \\ 名古屋大学医学部医療薬学 $\dagger^{1}$, 同附属病院薬郕部 $\dagger^{2}$, 同附属病院分院薬剂部 ${ }^{3}$
}

\section{Effect of Co-medications on Plasma Concentrations of Zonisamide}

\author{
MASAHIKo ShINODA ${ }^{*}{ }^{3}$, MASAHIRo AKITA $\dagger^{2}$, MASAYA HASEgaWA $\dagger^{2}$, \\ TAKAAKI HASEgAWA $\dagger^{2}$ and TOSHITAKA NABESHIMA $\dagger^{1,2}$ \\ Department of Neuropsychopharmacology ${ }^{1}$ and Hospital Pharmacy ${ }^{3}$, \\ Nagoya University School of Medicine, and Department of Hospital Pharmacy, \\ Nagoya University Branch Hospital $\dagger^{3}$
}

( $\left.\begin{array}{l}\text { Received January 9, } 1995 \\ \text { Accepted April 17, } 1995\end{array}\right)$

Zonisamide (ZNS), a new antiepileptic drug which features a wide antiepileptic spectrum, is commonly prescribed concomitantly with other drugs. However, there appears to be little data on the drug interaction of ZNS with other coadministered drugs. Concentrations of ZNS and co-medications in plasma were measured simultaneously by HPLC. The ratio of plasma concentration to the administered dose of ZNS in the monotherapy was significantly higher than that in the polytherapy $(P>0.05)$. When co-medications numbered more than two, the ratio was significantly decreased compared with ZNS alone, indicating the possibility that co-medications induce decreases in plasma concentration of ZNS. The present findings provide useful information that the monitoring of plasma concentration of ZNS is needed to adjust dosage regiments of ZNS in the polytherapy.

Keywords—zonisamide, HPLC, drug interaction, plasma concentration/dose ratio

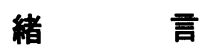

ゾニサミド(ZNS) はわが国で開発された新し い抗てんかん薬で，発作型からみて広い発作抑制 効果スペクトルを有し, 従来の薬物によっても十 分にコントロールできない難治性てんかん発作に あ有効であることが報告されている1-3).ZNS は, その歴史が浅いため他の抗てんかん薬と比較し

$\dagger^{1,2}$ 名古屋市昭和区鶴舞町 65; 65, Tsurumai-cho, Showa-ku, Nagoya, 466 Japan

$\dagger^{3}$ 名古屋市東区大幸南 1-1-20; 1-1-20, Daikominami, Higashi-ku, Nagoya, 461 Japan
て，単独で使用されることが少なく，多剤併用さ れていることが多い，当院に怙いても単独投与よ りも他の抗てんかん薬と併用される場合が多い。 しかし，ZNSの血漿中濃度に及ぼす併用薬剤の中 止怙よび投与量の増減の影響についてはほとんど 報告されていない，そこで，われわれは ZNS 服 用患者の血漿中 ZNS 濃度を測定し，ZNS の血墏 中濃度と投与量の関係 $(\mathrm{C} / \mathrm{D}$ 比) より血漿中 ZNS 濃度に及ぼす併用薬剂の中止や投与量の増減の影 響について検討し，新たな知見を得たので報告す る. 


\section{実 験 方 法}

\section{1. 患者および検体}

当院で受診している ZNS 服用患者 105 名の TDM 業務で用いた血漿サンプル 140 検体を対象 とした．年齢は $3 \sim 24$ 歳，ZNS の投与量は 1.37 〜 $16.67 \mathrm{mg} / \mathrm{kg} / \mathrm{day}$ であった. すべての患者の腎 機能および肝機能は正常であった。また，採血は 投与 2 時間後に行っだ)。 血液サンプルは遠心分 離後, その血漿をー $40^{\circ} \mathrm{C}$ で涷結保存した。なお, 対象の患者は 3 カ月以上 ZNSを服用しており, 症状が安定していることから，ZNS 濃度がすでに 定常状態に達していると考えられる.

\section{HPLC 法による ZNS の測定}

ZNSと使用頻度が高い他の抗てんかん薬を短時 間に同時定量することが可能な篠田ら5)の HPLC 法を改変し, 再現性および信頼性について検討し た. HPLC は LC-4A システム(島津, 京都), カ ラムは逆相カラム Cosmosil $5 \mathrm{C}_{8}$ (島津, 京都) を用いた。 また，クロマトグラフィーの条件は移 動相がアセトニトリルと $0.005 \mathrm{M} \mathrm{KH}_{2} \mathrm{PO}_{4}$ の混 液 (31:69), 検出器の UV 波長は $210 \mathrm{~nm}$, 流速 は $1 \mathrm{ml} / \mathrm{min}$, サンプル注入量は $10 \mu \mathrm{l}$ とした．前 処理法は，血漿 $100 \mu \mathrm{l}$ に内部標準物質（p-ヒドロ キシ安息香酸メチル $3 \mu \mathrm{g} / \mathrm{ml}$ ) を含むアセト ニト リル $500 \mu \mathrm{l}$ を加え， 1 分間混合後，遠心分離する ことにより除蛋白し，その上清を HPLC に注入 した. 薬物濃度は内部標準物質とのピーク高さ比 により算出した．測定の対象薬物とその代謝物の らちZZN，プリミドン，フェニトインは大日本製 薬, エトサクシミド, フェノバルビタールは三共, カルパマゼピン, カルバマゼピン -10,11-エポキ シドは日本チバガイギー，スルチアムはバイェル
薬品より提供を受けた。メフォバルビタールは東 京化成, フェニルェチルマロンフミドは Aldrich Chemical Company, Inc. より購入した. さら に，16名の患者血漿について測定原理を異にする Markit 法6) を用いて ZNS の血漿中濃度を測定 し, 両者の測定値の比較検討を行った.

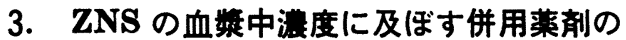

\section{影管}

ZNS の C/D 比と併用薬剂数との関係を検討し た.また， 1 剂併用時において比較的併用例の多 いフェニトインとの併用群について，その投与量 と ZNS の C/D 比との関係についても検討した. 有意差検定には one-way ANOVA およびScheffe F-test を用い， $P<0.05$ を有意差とした。

結果

\section{HPLC 法による ZNS の血等中㴽度の測定} HPLC法の精度を検討するため，ZNS拉よび併 用頻度の高い抗てんかん薬とその代謝物につい て，3 種類の既知濃度のスパイクサンプルを各 5 回測定した. Table 1 に示すように, ZNS の同 時再現性は変動係数 (C.V.) が $3 \%$ 以下で, 回収 率は 99.0 103.9\% と, 本法の再現性および信頼 性が高いことが明らかになった，Markit 法によ る測定値 $(x)$ と HPLC 法による測定值（y）の 回帰直線は $\mathrm{y}=1.095 \mathrm{x}-0.883$ で, 相関係数 $\mathrm{r}=$ $0.984, P<0.01$ と有意な相関を示した(Fig. 1).

また，Fig. 2 に示すようにZNS およびその併 用薬剤のピークの分離は良好であり，併用薬剤に よるZNS の定量に対する妨害は認められなかっ た.

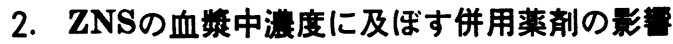
併用薬剤の種類とその症例数を Table 2 に示

Table 1. Accuracy for HPLC Method

\begin{tabular}{ccccc}
\hline Drug & $\begin{array}{c}\text { Spiked Conc. } \\
(\mu \mathrm{g} / \mathrm{ml})\end{array}$ & $\begin{array}{c}\text { Observed Conc. } \\
(\mu \mathrm{g} / \mathrm{ml})\end{array}$ & $\begin{array}{c}\text { C.V. } \\
(\%)\end{array}$ & $\begin{array}{c}\text { Recovery } \\
(\%)\end{array}$ \\
\hline Zonisamide & 10 & 10.39 & 0.87 & 103.9 \\
& 20 & 19.81 & 2.65 & 99.0 \\
& 40 & 39.70 & 1.02 & 99.3 \\
\hline
\end{tabular}

Each value was the mean of five determinations. 


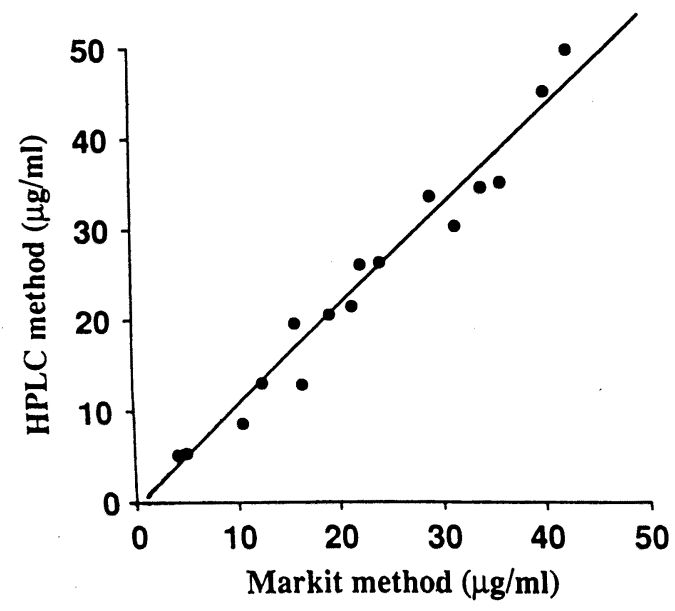

Fig. 1. Relationship between Markit Method and HPLC Method in Plasma Concentration of Zonisamide
Table 2. Drug Name of Co-medications with Zonisamide (ZNS)

\begin{tabular}{lc}
\hline Co-medication & Number of samples \\
\hline None & 6 \\
Valproic acid & 67 \\
Phenytoin & 58 \\
Carbamazepine & 50 \\
Clonazepam & 40 \\
Phenobarbital & 32 \\
Primidone & 6 \\
Diazepam & 6 \\
Mephobarbital & 3 \\
Other Drugs & 18 \\
\hline
\end{tabular}

した. また，すべての患者についての ZNS の投 与量 $(\mathrm{x})$ と血漿中濃度 $(\mathrm{y})$ の関係を Fig. 3 に 示した。回帰直線は $\mathrm{y}=2.716 \mathrm{x}+1.824$ で, 相関 係数 $\mathrm{r}=0.718, \mathrm{P}<0.01$ と有意な直線関係が認

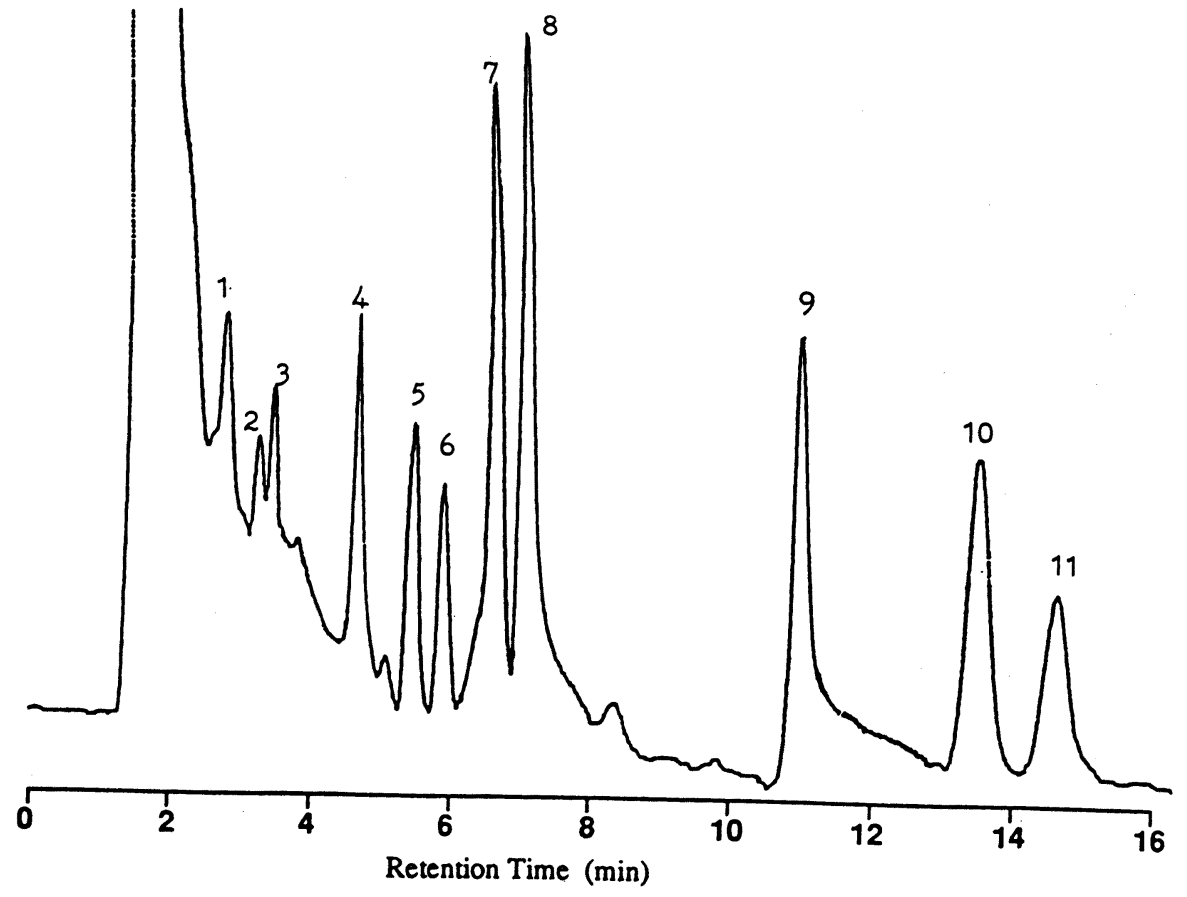

\section{Phenylethylmalonamide 2.Primidone \\ 3.Ethosuximide \\ 4.Sultiame \\ 5.Zonisamide \\ 6.Carbamazepine-10,11-epoxide}

\section{Phenobarbital}

$$
\begin{aligned}
& \text { 8.I.S. (Methyl p-hydroxybenzoate) } \\
& \text { 9. Carbamazepine } \\
& \text { 10. Phenytoin } \\
& \text { 11. Mephobarbital }
\end{aligned}
$$

Fig. 2. HPLC Chromatogram for Antiepileptic Drugs in Human Plasma 


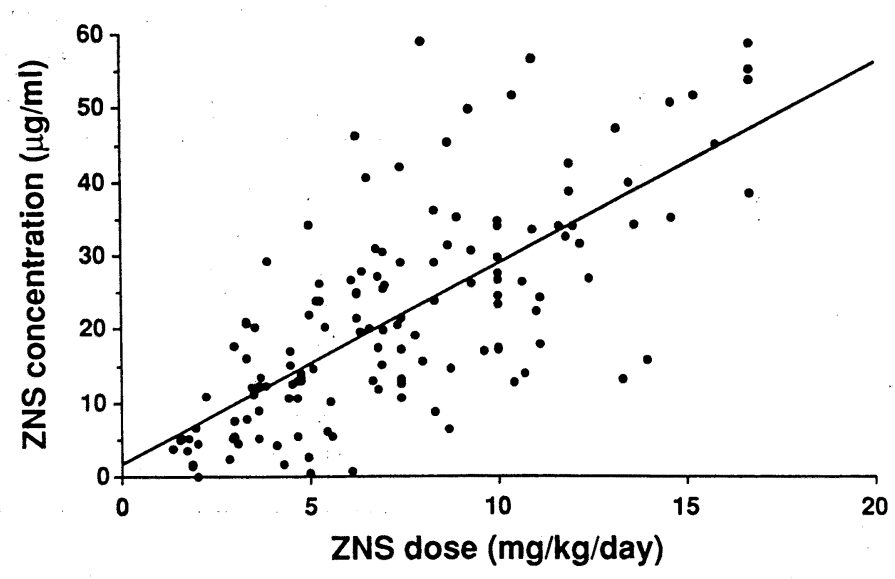

Fig. 3. Correlation between Dose and Plasma Concentration of Zonisamide (ZNS)

められた。

ZNSの投与量に対する血漿中濃度の比 (C/D比) に及ぼす併用薬剤数の影響を Fig. 4 に示した. ZNS の C/D 比は併用薬剤によって有意に減少 し，また，併用薬剤数の増加に伴い減少した。単 独投与群 $(4.36 \pm 0.34)$ と 1 剂併用群 $(3.31 \pm 0.28)$ との間には有意な差が認められなかったが， 2 剂 以上の併用群では有意な低下が認められた。

さらに， 1 剂併用の症例の中で，比較的併用例 の多かったフェニトインの投与量と ZNS の C/D 比との関係を ZNS 単独投与群も含めて 検討し

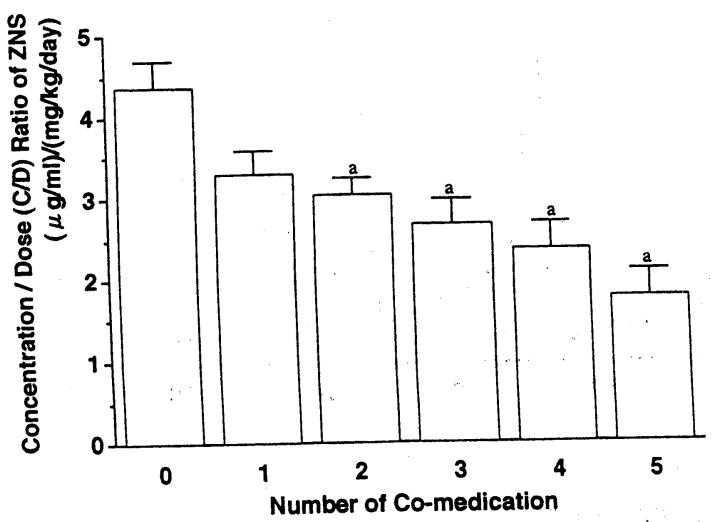

Fig. 4. Effect of Number of Co-medication on the Ratio of Concentration/Dose of ZNS

Each value represents the mean \pm S.E. $\mathrm{a}: \mathrm{P}<0.05$ vs $\mathrm{ZNS}$ alone (Scheffe $\mathrm{F}-$ test).
た. Fig. 5 に示したように, 回帰直線は $\mathrm{y}=$ $0.231 \mathrm{x}+4.750$ で, 相関係数 $\mathrm{r}=-0.701, \mathrm{P}<$ 0.05 とフェトインの投与量の増加に伴い, $\mathrm{ZNS}$ の C/D 比は滅少した.

\section{考察}

先に, 我々は複数の抗てんかん薬の簡便で精度 の高いHPLC 法による同時分離測定法を開発し た ${ }^{5)}$. 今回，この方法を用いて日常の TDM 業務 におけるサンプル中の抗てんかん薬 ZNS と他の 抗てんかん薬を同時分離測定し，ZNSの投与量と 血漿濃度の関係 $(\mathrm{C} / \mathrm{D}$ 比) に及ぼす併用薬の影響 について検討した。

ZNS はその有効血漿中濃度範囲が $10 \sim 30 \mu \mathrm{g} /$ $\mathrm{ml}^{7)}$ または $20 \sim 30 \mu \mathrm{g} / \mathrm{ml}^{4)}$ と狭く，また，定常 状態に括ける血墏中濃度と投与量の関係が非線形 性であるといわれている4,8).ZNS は肝蔵で薬物 代謝酵素チトクロムP-450により代謝を受け、イ ソキサゾール環が開裂した後, グルクロン酸抱合 され排泄される9-12)，したがって，非線形を示す 理由の一つとして代謝過程における飽和が考えら れている8). 逆に, ZNS の血漿中濃度と投与量の 関係が線形であるといら報告もある。福島ら²は 同一患者を用いて，異なった投与量の ZNS を投 与した場合の血漿中濃度データについて検討した ところ, ZNS の血漿中濃度が投与量に比例して上 昇することを報告している. 小野ら ${ }^{13)}$ は多施設で 


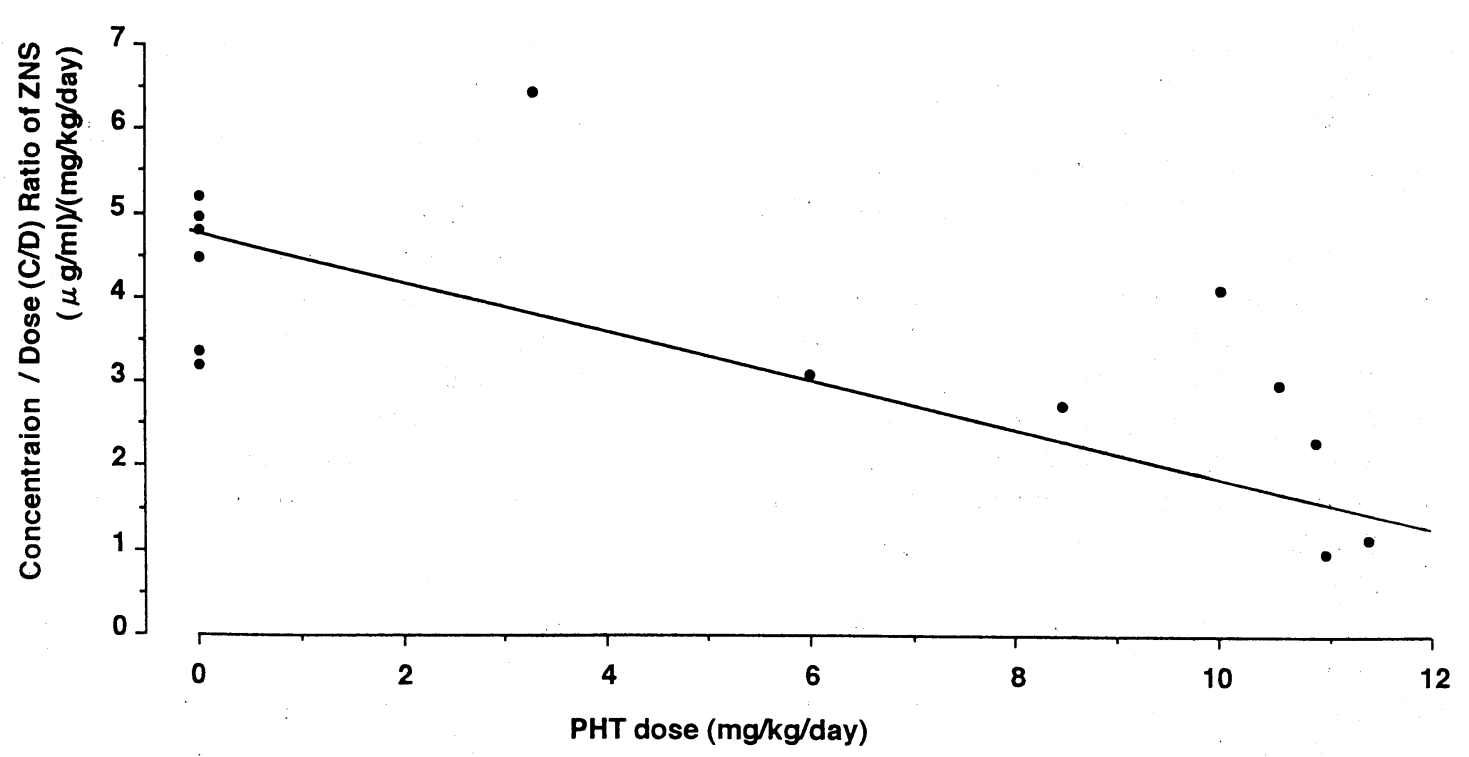

Fig. 5. Correlation between Concentration/Dose Ratio of Zonisamide (ZNS) and Dose of Phenytoin (PHT)

得られた 456 例について検討したところ, ZNS の 投与量が $15 \mathrm{mg} / \mathrm{kg} / \mathrm{day}$ までは線形性が認められ たと報告している. 本研究で対象とした $1.37 〜$ $16.67 \mathrm{mg} / \mathrm{kg} / \mathrm{day}$ の投与量範囲では, Fig. 3 に 示したよらに ZNS の投与量と血漿中濃度の関係 は福島ら，小野らの報告にほぼ一致した結果が得 られた。

ZNSは歴史が浅いために，単独で投与されるケ 一スが少なく，他の抗てんかん薬と併用される場 合が多い，抗てんかん薬の中には薬物代謝酵素を 誘導するものがあることから，併用時にはZNS の 血漿中濃度が変化する可能性がある ${ }^{9,13-16)}$. 緒方 ら ${ }^{14)}$ は ZNS の単剤投与群における C/D 比が多 剂併用投与群よりも大きくなること，多剤併用時 に拈いても線形性は認められるが，単剂併用時よ りも相関が弱くなることから，多剤併用時に拈け る ZNS の血墏中濃度を予測することが難しいこ とを示唆している. 併用された抗てんかん薬個々 については，フェニトイン14)，カルバマゼピン13) やバルプロ酸 ${ }^{2)}$ の併用により，ZNS の C/D 比が 低下すると報告されている。本研究においても， 多剂併用群において ZNS の C/D 比は低下してい た.このことは, 併用されていた抗てんかん薬が 主にバルプロ酸, フェニトイン,カルバマゼピンで
あったことに起因すると考えられる，本研究で検 討したフェニトイン 1 剂併用群ではフェニトイン 錠剤の末を全例に投与したが，フェニトインの投 与量に比例して ZNS の C/D 比が有意に低下する 成績を得た.フェニトイン, カルバマゼピンはい ずれも肝薬物代謝酵素を誘導することから ZNS の代謝が促進されたものと考えられる13-16). バル プロ酸は肝薬物代謝酵素には影響を与えないが, フェニトインと同様に蛋白結合率が高い薬剤であ る、パルプロ酸が ZNS の蛋白結合率を低下させ る可能性が示唆されているが17,18)，ZNSの蛋白結 合率はほぼ40\%と低いことから蛋白結合率の変化 では説明できない他の要因が考えられる。この点 についてはさらに詳細な検討が必要であると思わ れる。

以上，ZNSに併用されている他の抗てんかん薬 を中止や減量する場合には, 血漿中 ZNS 濃度が 上昇する可能性があることから，TDM による慎 重な投与設計が望まれる.

\section{引用文 献}

1）武田明夫, 稲態順子, 清水章子, 薬 理 と治 療, 15, 397-405 (1987).

2）福島克之, 八木和一, 清野昌一, 藤原健樹, 渡辺 
雅子, 村中秀樹, 工藤達也, 岡部稳, 大谷和正, 寺内 昇，沼田陽一，小児科臨床，40，221-228 (1987).

3）香坂雅子, 角哲夫, 千葉達雄, 田中 哲, 福島順 子, 山下 格, 山内俊雄, 臨床医薬, 3, 1343-1352 (1987).

4) Y. Hashimoto, A. Odani, Y. Tanigawara, M. Yasuhara, T. Okuno, and R. Hori, Bio. Pharm. Bull., 17, 323-326 (1994).

5）篠田正彦, 秋田昌宏, 上能伊公雄, 北澤式文, 日 本薬学会第 104 年会講演要旨集, 752 (1984).

6) 竹内恒夫, 春日井一正, 岡田成彦, 竹内勝彦, 塩 野年昭, 戸田敏夫, 医薬ジャーナル, 28, 327-331 (1992).

7）濱田耕一, 清野昌一, 臨床医, 17, 624-641 (1991).

8）西原カズョ, 澤田康文, 伊賀立二, T D M 研究, 10, 47-50 (1993).

9) T. Ito, T. Yamaguchi, H. Miyazaki, Y. Sekine, M. Shimizu, S. Ishida, K. Yagi, N.Kakegawa, M. Seino, and T. Wada, Arzneim.-Forsch./ Drug Res., 32, 1581-1586 (1982).

10）小宮守善, 大森 栄, 仲佐啓祥, 力久忠昭, 金久
保好男, 北田光一, 第 7 回薬物動態学会年会講演 要旨集, 118 (1992).

11）仲佐啓祥, 小宮守善, 大森 栄, 力久忠昭, 金久 保好男, 北田光一, 第 7 回薬物動態学会年会講演 要旨集, 119 (1992).

12) D.D. Stiff, J.T. Robichean, and M.A. Zemaitis, Xenobiotica, 22, 1-11 (1992).

13）小野常夫, 八木和一, 清野昌一, 精神医学, 30, 471-482 (1988).

14）緒方 明, 沼田陽一, 宮本憲司朗, 宮川太平, 精 神治療学, 2, 433-439 (1987).

15) L.M. Ojemann, R.A. Shastri, A.J. Wilensky, P.N. Friel, R.H. Levy, J.R. Mclean, and R.A Buchanan, Ther. Drug Monitor., 8, 293-296 (1986).

16）井尻好雄, 大井一英, 鈴木 兴, 福岡栄介, 吉成 昌郎, T D M研究, 10, 51-56 (1993).

17) M. Kimura, N. Tanaka, Y. Kimura, K. Miyake, T. Kitaura, H. Fukuchi, and Y. Harada, Chem. Pharm. Bull., 40, 193-195 (1992).

18）井尻好雄, 大井一英, 鈴木 薏, 福岡栄介, 古家 鞆弘, 吉成昌郎, 玉井 浩, 病院薬学, 20, 207212 (1994). 